\title{
Antigen Recognized by Monoclonal Antibodies to Mesencephalic Neural Crest and to Ciliary Ganglion Neurons Is Involved in the High Affinity Choline Uptake Mechanism in These Cells
}

\author{
K.F. Barald \\ Department of Anatomy and Cell Biology, Program in Neuroscience, Program in Cell and Molecular Biology, \\ University of Michigan Medical School, Ann Arbor
}

High-affinity choline uptake mechanisms are among the characteristics of cholinergic neurons such as the ciliary and choroid subpopulations in the ciliary ganglion (Barald and Berg, 1979).

We have produced three monoclonal antibodies (Mabs), two of which were made to 8-day embryonic chick ciliary ganglion (CG) neurons (CG-1, CG-4) (Barald, 1982) and one of which was made to cultured mesencephalic neural crest (NC) cells (CG-14) removed from the embryo $31 \mathrm{hr}$ after incubation. We have shown that all three Mabs label a common 75 $\mathrm{kD}$ antigen present on the cell surface of both CG neurons and NC cells (Barald, 1988).

Here we report that the CG-1 and CG-4 antibodies, used in the same ratios in which they are synergistically cytotoxic for both the CG and NC cells (Barald, 1988), and Mab CG-14 alone, have specific effects on the high-affinity choline uptake mechanism (HACU) of CG neurons and isolated antigen-positive NC cells in the absence of complement. CG-1 and CG-4 in ratios of $8 / 1$ (the same ratios that are used to kill the CG and the NC subpopulation), but neither singly, inhibit the HACU of CG neurons by $40 \%$ and that of isolated antigen-positive NC cells by $75 \%$. However, CG-14 alone, at $1 \mu \mathrm{g} / \mathrm{ml}$, inhibits the HACU of both CG neurons and isolated NC cells by $95 \%$.

None of the antibodies had an effect on numbers of ouabain binding sites (a measure of the $\mathrm{Na}^{+} / \mathrm{K}^{+}$ ATPase) or cell surface acetylcholinesterase (AChE) of CG neurons or NC cells isolated by "no-flow" fluorescence cytometry with a Meridian Instruments ACAS470 cytometer. CG or NC cells grown in the presence of the antibodies without complement grow and remain healthy for many weeks. They exhibit no difference in morphology, protein content, lactate dehydrogenase activity (LDH), or division time from untreated sister cultures.
Therefore, the antigen recognized by all three Mabs may be involved in a high-affinity choline uptake mechanism, a common characteristic of cholinergic neurons. The Mabs themselves may possibly label some element of the high-affinity transporter or a proximal membrane component. This implies that such a high-affinity uptake mechanism is present in the subpopulation of $\mathrm{NC}$ cells at early times in development. If these cells in fact are destined to contribute to the avian CG, these characteristics are present in the subpopulation before the NC cells take on a neuronal morphology.

Key words: culture, chick, choline transport, inhibition by monoclonal antibodies

\section{INTRODUCTION}

Cholinergic central nervous system neurons (Bremer and Greenberg, 1961; Ansell and Spanner, 1967; Browning and Schulman, 1968; Baughman and Bader, 1977; Barald and Berg, 1978, 1979a; Rainbow et al., 1984; Sandberg and Coyle, 1985; Manaker et al., 1986) as well as peripheral neurons such as those of the parasympathetic chick ciliary ganglion (Suszkiw and Pilar, 1976; Barald and Berg, 1979b) and the nodose ganglion (Palouzier et al., 1987) have high-affinity uptake mechanisms for choline. Because the neurons cannot make choline de novo, they must take it up from the surrounding milieu both for the production of the neurotransmitter acetylcholine (ACh) (Yamamura and Snyder, 1972, 1973) and for the synthesis of membrane components necessary

Received June 6, 1988; revised June 21, 1988; accepted June 23, 1988.

Address reprint requests to Dr. Kate F. Barald, Department of Anatomy and Cell Biology, University of Michigan, Box 0616, Ann Arbor, MI 48109. 
for the elaboration of rapidly evolving neurites (Barald and Berg, 1979a,b; Glanville et al., 1987), even when the concentration in the external milieu is very low (Groth et al., 1958).

The two populations of cholinergic neurons in the chick ciliary ganglion (CG), the ciliary and choroid neurons (Marwitt et al., 1971; Landmesser and Pilar, 1972), have high-affinity uptake mechanisms for choline in culture with an apparent Michaelis constant $\left(\mathrm{K}_{\mathrm{m}}\right)$ of $0.3 \mu \mathrm{M}$ (Barald and Berg, 1979b). High affinity choline uptake in CG neurons appears to be sodium-dependent and sensitive to specific inhibitors, such as hemicholinium-3 (HC-3) (Barald and Berg, 1979b), which have been shown to inhibit the HACU of brain synaptosomes (Yamamura and Snyder, 1972, 1973).

Three monoclonal antibodies (Mabs) have been isolated and partially characterized. Two, called CG-1 and CG-4, were made to chick ciliary ganglion neurons of 8day embryonic chicks and label both the ciliary and choroid neuronal populations in chick and quail and a small (5\%) subpopulation of chick and quail mesencephalic neural crest cells at $31 \mathrm{hr}$ after incubation. They do not label any other neuronal or nonneuronal cells. Identification of a third neural-crest-generated Mab, CG14 , and the discovery (see preceding paper, Barald, 1988) that all three Mabs labeled a common antigen in both CG and NC cells strengthened our hypothesis that the NC subpopulation might contribute to one or both populations of cholinergic neurons in the CG (Barald, 1982; Barald and Wessells, 1984; Barald, 1988). The mesencephalic NC is known to be the source of the neurons in the CG (Narayanan and Narayanan, 1978; Noden, 1978; LeDouarin et al., 1978). All three Mabs identified CG and NC cells with high levels of choline acetyltransferase (ChAT) activity in mixed cultures of antigen-positive and antigen-negative $\mathrm{NC}$ cells from early embryos (Barald, submitted). We found that the ChAT activity was abolished in such mixed cultures if the CG-1 and CG-4 antibodies and complement were used to eliminate the antigen-positive NC subpopulation and that no other cells with ChAT activity appeared subsequently in culture during the next 3 weeks. Taken together, these data suggest that the NC subpopulation might have cholinergic traits without exhibiting a neuronal morphology.

In this report, we have further characterized the antigen(s) recognized by the three Mabs described in the preceding paper (Barald, 1988). We have found that both CG-1 and CG-4 Mabs together (in the absence of complement), and the CG-14 Mab alone, significantly affect the high-affinity choline uptake system without affecting other cell-surface-associated functions, such as the sodium-independent low-affinity choline uptake, ouabain binding (a reflection of $\mathrm{Na}^{+} / \mathrm{K}^{+}$ATPase), or cell surface markers such as AChE. The antibodies also did not affect the general health, morphology, division times, protein content or lactate dehydrogenase (LDH) levels of the cells in which antibody treatment profoundly affected the HACU. CG- 14 , even at very low $(1 \mu \mathrm{g} / \mathrm{ml})$ concentrations and in the absence of complement, eliminates the HACU in both CG neurons and an antigen-positive population of NC cells isolated from monolayer cultures with a no-flow cytometer (Meridian ACAS470).

The antibodies can now be used both to characterize the HACU mechanism on a cellular and molecular level and to study its development.

\section{MATERIALS AND METHODS}

\section{Animals, Cultures of CG Neurons, and NC Cells}

The preceding paper (Barald, 1988) contains methods and descriptions of these preparations. Cultures were 1) used for determinations of high- and low-affinity choline uptake, ouabain binding, AChE labeling, protein and LDH determinations and cell counts in the presence of ethidium bromide and acridine orange (Barald, 1982; Barald, 1988), which were used to determine viability; 2) analyzed for immunofluorescence by light microscopy or no-flow ACAS470 cytometry (see below) before or after subculturing; 3) used in mixed cultures of antigenpositive and antigen-negative NC cells for immunoablation experiments with antibodies and complement; and 4) used for isolation of subpopulations by no-flow cytometry with a Meridian Instruments ACAS470 Cytometer (Barald, submitted; Barald and Wolff, in preparation).

Cultures of spinal cord neurons from embryonic 4day chick embryos (Hamburger and Hamilton, 1951) (stage 24) were prepared as in Barald and Berg (1978, 1979a).

\section{High Affinity and Low Affinity Choline Uptake}

CG neurons obtained from 8-day embryonic chick (Hamburger and Hamilton, 1951) (stage 34) and spinal cord (SC) neurons from 4-day chick embryos (Hamburger and Hamilton, 1951) (stage 24) were grown in tissue culture; they were examined after 4-8 days in culture. Mesencephalic NC cells were obtained from 31hr embryos (Hamburger and Hamilton, 1951) (stage $9 \pm$ ), and tested after various times in culture before and after subculturing, and before and after antigen-negative cells were ablated by laser on a no-flow cytometer (Meridian Instruments ACAS470) (see below). CG and SC neurons and $\mathrm{NC}$ cells were given ${ }^{3} \mathrm{H}$-choline [0.1 to 1 $\mu \mathrm{M}$; specific activity $72 \mathrm{Ci} / \mathrm{mmol}(\mathrm{NEN})]$ in the presence or absence of specific inhibitors of high-affinity choline uptake (Barald and Berg, 1979); $10 \mu \mathrm{M}$ Hemicholinium3 , a specific inhibitor of the high-affinity mechanism, or sodium deprivation (replacement of all sodium in the medium with lithium) was used to block the high-affinity 
component of the uptake. The low-affinity component in CG neurons, SC neurons and NC cells is sodium-independent (Barald and Berg, 1978, 1979a,b) (see below) and can be determined if the HACU is blocked. All reagents were as described in Barald and Berg (1978, 1979a,b).

CG-1 antibody (in ranges from 0.1 to $25 \mu \mathrm{g} / \mathrm{ml}$ ) or CG-4 antibody (in ranges from 0.1 to $25 \mu \mathrm{g} / \mathrm{ml}$ ) were also used alone and in various combinations to block the uptake. Michaelis constants and various other parameters, including inhibition of the high- and low-affinity choline uptake mechanism were determined under saturating and nonsaturating conditions, as described in Barald and Berg (1979b). CG-14 was used at concentrations of $1 \mu \mathrm{g} / \mathrm{ml}$.

High-affinity choline uptake is expressed as p moles of choline taken up per minute per milligram of protein (extrapolated) at a level of $0.1 \mu \mathrm{M}$ choline during a 5min period. The experiment was repeated four times with three cultures contributing to determinations at each choline concentration. Antibodies and/or specific inhibitors were preincubated with cells for $15 \mathrm{~min}-1 \mathrm{hr}$, as were the inhibitors in our earlier studies (Barald and Berg, 1978; Barald and Berg, 1979a,b).

\section{Effect of the Antibodies on Other Cell Surface Components}

Ouabain binding. Ouabain binding sites, a measure of cell surface $\mathrm{Na} / \mathrm{K}$ ATPase, were measured on passaged $\mathrm{NC}$ cells as described by Hootman and Ernst (1988), except that cells were not released from culture dishes and the determinations were done on $12-\mathrm{mm}$ thermanox cover slips. Cells were incubated in $\left[{ }^{3} \mathrm{H}\right]$ ouabain $(\mathrm{NEN})$ at $0.1-10 \mu \mathrm{M}(1.8 \mu \mathrm{Ci} / \mathrm{ml})$ and $0.2 \mu \mathrm{Ci} / \mathrm{ml}\left[{ }^{14} \mathrm{C}\right]$ sucrose, which was included as an extracellular space marker (Hootman and Ernst, 1988). The coverslips were washed and incubated in $0.5 \mathrm{M} \mathrm{NaOH}$ at $50^{\circ} \mathrm{C}$ overnight to dissolve cells for scintillation counting. The $\mathrm{NaOH}$ was neutralized with $\mathrm{HCl}$ before the addition of the scintillation cocktail (Beckman Ready Solve). Total ouabain associated with each culture was normalized for cell number and corrected for residual medium contamination with the $\left[{ }^{14} \mathrm{C}\right]$ sucrose values (as in Hootman and Ernst, 1988). All measurements of $\left[{ }^{3} \mathrm{H}\right]$ ouabain binding sites were done under saturating conditions.

Acetylcholinesterase. The presence of cell surface AChE activity was monitored by a modification of the method of Karnovsky and Roots (1964), which we have used previously (Barald and Berg, 1979a) or the presence of the enzyme was followed with a monoclonal antibody to AChE (Barald, unpublished). Spectrophotometric determination of acetylcholinesterase activity was performed on unfixed cell cultures by a micro-method (Barald, 1974), which is a modification of the method of Ellman et al. (1961).

\section{Lactate Dehydrogenase (LDH) Activity}

LDH activity was determined in cell homogenates on a Gilford Response Spectrophotometer as previously described (Barald et al., 1987). Pyruvate and $\beta$-nicotinamide adenine dinucleotide (reduced form) were from Sigma.

\section{Protein}

Protein determinations were made by a micromethod, a modification of the Lowry method described in the preceding paper (Barald, 1988).

\section{Cell Numbers, Cell Viability}

Cell numbers and viability with time in culture were determined as described in the preceding paper (Barald, 1988).

\section{Analysis of Antibody Binding by Immunohistochemistry and Immunoablation Experiments}

Analysis of immunohistochemical labeling with the antibodies and fluorescent second-step labels is detailed in the preceding paper (Barald, 1988). Abolition of antigen-positive cells with antibody and complement was performed as described in the preceding paper (Barald, $1988)$ and in Barald (1982).

\section{Elimination of Antigen-Negative NC Cells by No-Flow Cytometry}

In a preliminary report (Barald, 1983), we showed that we could separate antigen-positive from antigennegative populations of neural crest cells by fluorescence flow cytometry and that the two subpopulations had very different properties in culture. However, recovery of viable cells for experiments was extremely low, and at least 100 (usually 240) embryos had to be used for the preparation of $\mathrm{NC}$ cells in order to isolate enough cells for a single experiment. To alleviate this problem, we needed a cell sorter that was capable of sorting anchored cells on monolayers rather than from cell streams. The ACAS470 cytometer (Schindler et al., 1985) is such an instrument. We have used this instrument to eliminate the antigen-negative or antigen-positive (recognized by fluorescent monoclonal antibody binding) populations of NC cells.

In order to eliminate antigen-negative NC cells before assessment of effects of Mabs CG-1, -4 or -14 on ouabain binding sites, cell surface $\mathrm{AChE}$, and high- and low-affinity choline uptake, neural crests were isolated from embryos at 28-31 hr after placing eggs in the incubator (Hamburger and Hamilton, 1951) (Stage 9). The cells were placed on saran-wrap cover slips shadowed with carbon in 35- $\mathrm{mm}$ (Falcon) tissue culture plastic dishes in plating rings $5 \mathrm{~mm}$ in diameter, which were sealed to the cover slips with medium. The unfixed NC 
cells were labeled with CG-1 or CG-4 and a second-step fluorescent antibody in tissue culture at $6^{\circ} \mathrm{C}$ after as few as 4-8 $\mathrm{hr}$ in culture. It is important to note that these cells can be stained in the embryo (Barald and Wolff, in preparation). As soon as the crests are removed, the subpopulation $(5 \%)$ of cells can be stained with the antibody in fresh-squash preparations. The tissue culture dishes were placed in a chilled metal block plate holder adapted for the stage of a Meridian Instruments ACAS470 cytometer. The chilled block maintains the temperature at or below $10^{\circ} \mathrm{C}$ for up to $10 \mathrm{~min}$ (Barald, in preparation). After scanning and identification of the labeled and unlabeled NC cells (fluorescent and nonfluorescent) and setting fluorescence levels for ablation, the unlabeled cells were laser-ablated (Barald, submitted).

The ACAS 470 (Schindler et al., 1985) is capable of saving the cells that label with fluorescently tagged antibodies from exposure to a destructive high-intensity argon laser beam. The surviving population can then be passaged. The high-speed computer-controlled two-dimensional stage moves cells past the beam for analysis. Each cell is examined, and since fluorescence levels below which the cell is to be ablated are set by the investigator, each cell is either destroyed by the radiant energy of the laser or selected for survival.

We laser-ablated the antigen-negative cell population on ten dishes of early mesencephalic neural crest cells (five crests per dish), and after carefully washing off the cell debris from the lysed cells and allowing the cells an interval of recovery $(1 \mathrm{hr})$ in the humidified $\mathrm{CO}_{2}$ incubator at $37^{\circ} \mathrm{C}$, we trypsinized and passaged the antigen-positive cells. The passaged NC cells, which we recovered at $85-90 \%$ (compared to $10-15 \%$ recoveries after flow cytometry; Barald, submitted), were allowed to grow in culture in a number of different media (Barald, submitted). The cells that were placed in media that promoted proliferation (Barald, submitted) underwent several cell divisions and provided us with a relatively large population of $\mathrm{A}^{+}$cells for these experiments. Antigen-negative cells $\left(\mathrm{A}^{-}\right)$could also be isolated by instructing the ACAS to ablate the fluorescently labeled cells in the culture. In this manner, we obtained both $\mathrm{A}^{+}$ and $\mathrm{A}^{-}$cells for study. All the examinations of cell surface properties and HACU were done on $\mathrm{A}^{+}$and $\mathrm{A}^{-}$ neural crest cultures (Barald, submitted).

\section{Iodinated Protein A Binding}

${ }^{125} \mathrm{I}$-protein $\mathrm{A}(50 \mu \mathrm{Ci} / \mu \mathrm{g} ; \mathrm{NEN})$ was used to determine the level of binding of antibodies CG-1, CG-4, and CG-14 to dissociated mesencephalic NC cells obtained from stage-9 (Hamburger and Hamilton, 1951) embryonic chick and to $C G$ neurons from stage 34 (8-day) embryonic chick. Studies were done on restoration of antibody-binding sites after trypsinization or after inter- nalization with concanavalin $\mathrm{A}$, in order to determine when to examine cultures for antibody or ouabain binding or cell surface $\mathrm{AChE}$ determinations. Binding to control cultures was determined by applying the antibody for 20 min, with subsequent washing (three times) and then applying ${ }^{125}$ I-protein $\mathrm{A}$ for $30 \mathrm{~min}$. Six cultures were used for each time point, and specific activities of number of counts bound/protein were determined in each case with a gamma counter.

In experimental cultures, trypsin treatment was carried out by exposing the cultures to $0.25 \%$ GIBCO trypsin solution in Modified Puck's saline with glucose (MPG), but without $\mathrm{Ca}^{++}$or $\mathrm{Mg}^{++}$, for 4-11 min. The trypsinization was stopped either by the addition of medium containing $20 \%$ horse, $20 \%$ fetal bovine, or $20 \%$ chicken serum or by addition of medium containing soybean trypsin inhibitor (Sigma) in concentrations determined for each trypsinization condition. Conditions were optimized for removal of antibody-binding components from cells. By varying the length of the recovery period allowed before testing, it was possible to get an estimation of the time that was required for the cell cultures to reinsert antibody binding sites.

Conditions for this type of experiment were first determined for CG neurons and then applied to NC cells. Antibody binding is expressed as a percentage of the radioactivity (determined by gamma counting) in control cultures labeled with ${ }^{125}$ I-protein A $(50 \mu \mathrm{Ci} / \mu \mathrm{g} ; \mathrm{NEN})$. In a parallel series of experiments, autoradiography was used to detect the numbers of cells that bound the protein A under each condition and for each time point. Results of the two series of experiments (percentages of experimental values compared to controls) were in agreement. Similar studies were done after Con-A-mediated internalization of antibody-binding sites.

\section{RESULTS}

\section{General Effects of the Monoclonal Antibodies on CG and NC Cells in Culture}

The presence of the antibodies CG-1, CG-4, or CG14 in the absence of complement, singly or in various combinations in concentration ranges from 0.1 to $25 \mu \mathrm{g} /$ $\mathrm{ml}$, had no effect on the morphology, general health, or longevity of the cultured CG neurons alone or on CG neurons in culture with embryonic skeletal muscle cells (Table I). In addition to measuring the effect of the antibodies on the cell surface parameters described below (see Fig. 3 and Other Cell Surface Components), we tested cultures grown in the presence of antibody for several measures of health and viability.

1. Morphology: cells grown with or without Mabs looked identical. Neurons retained their phase bright appearance and neurites and remained attached to the dish. NC cells remained stellate and did not round up. 
TABLE I. Effect of Mabs on CG Neurons and NC Cells in Culture in the Absence of Complement*

\begin{tabular}{|c|c|c|c|c|c|}
\hline Cell type & $\begin{array}{l}\text { Antibody } \\
(5 \mu \mathrm{g} / \mathrm{ml})\end{array}$ & $\begin{array}{c}\text { Protein in cultures } \\
\% \text { of control } \\
\end{array}$ & $\begin{array}{l}\text { LDH activity } \\
\% \text { of control }\end{array}$ & $\begin{array}{l}\text { Total viable cells } \\
\% \text { of control }\end{array}$ & $\begin{array}{c}\text { Morphology } \\
\text { compared } \\
\text { to control } \\
\end{array}$ \\
\hline \multirow[t]{4}{*}{ CG } & CG-1 & $95 \pm 2$ & $101 \pm 1$ & $118 \pm 10$ & $\begin{array}{l}\text { same; phase } \\
\text { bright cells } \\
\text { with long } \\
\text { neurites }\end{array}$ \\
\hline & $\mathrm{CG}-4$ & $97 \pm 5$ & $96 \pm 4$ & $102 \pm 9$ & same as control \\
\hline & $\begin{array}{c}\text { CG-1 }+ \\
\text { CG-4 } \\
(5 \mu \mathrm{g} / \mathrm{ml} / \\
0.6 \mu \mathrm{g} / \mathrm{ml})\end{array}$ & $105 \pm 4$ & $97 \pm 6$ & $110 \pm 5$ & same as control \\
\hline & CG-14 & $111 \pm 7$ & $101 \pm 5$ & $97 \pm 4$ & same as control \\
\hline \multirow[t]{4}{*}{$\mathrm{NC}$} & CG-1 & $113 \pm 9$ & $97 \pm 3$ & $104 \pm 11$ & $\begin{array}{l}\text { same; stellate } \\
\text { cells, no } \\
\text { vacuoles, } \\
\text { not round }\end{array}$ \\
\hline & CG-4 & $98 \pm 6$ & $104 \pm 2$ & $100 \pm 4$ & same as control \\
\hline & $\begin{array}{c}\mathrm{CG}-1+ \\
\mathrm{CG}-4 \\
(5 \mu \mathrm{g} / \mathrm{ml} / \\
0.6 \mu \mathrm{g} / \mathrm{ml})\end{array}$ & $97 \pm 1$ & $102 \pm 5$ & $93 \pm 6$ & same as control \\
\hline & CG-14 & $96 \pm 8$ & $99 \pm 4$ & $101 \pm 3$ & same as control \\
\hline
\end{tabular}

${ }^{\text {a }}$ Protein concentration of CG cultures in controls was $301 \pm 16 \mu \mathrm{g} / \mathrm{ml}$ at 1 week in culture; 6 CGs from an 8-day embryo were initially plated. Protein concentration for the sorted NC cells was $111 \pm 20 \mu \mathrm{g} / \mathrm{ml}$ at 3 days after sorting.

${ }^{\mathrm{b}} \mathrm{LDH}$ activity was $409+22 \mathrm{IU} /$ culture for CG neurons at 1 week in culture in the absence of the antibody and $176 \pm 14 \mathrm{IU} /$ culture for NC cells 3 days after sorting.

Total number of CG neurons at 1 week in the absence of antibody was $5.1 \pm 0.3 \times 10^{5}$ per culture; for NC cells, it was $3.98 \pm .6 \times 10^{4}$ per culture after 3 days.

*All values are expressed as the mean \pm standard error of the mean $(n=3)$.

2. Protein content of both cultures was the same.

3. Lactate dehydrogenase activity $(\mathrm{LDH})$, a measure of a cytoplasmic enzyme that reflects metabolic health of the cultures, was the same.

4. The cell numbers in both cultures remained the same over a 12-day period.

The Mabs did not affect CG neurons' ability to make contacts with cultured chick skeletal muscle, although synaptogenesis was subsequently inhibited (Barald and Wolff, in preparation). They also did not affect the growth of the antigen-positive $\left(\mathrm{A}^{+}\right)$or antigen-negative $\left(\mathrm{A}^{-}\right) \mathrm{NC}$ cells before or after subculturing (post ACAS470 sorting) in culture for up to 2.5 weeks (see also Barald, 1982; Barald, 1988, the preceding paper).

\section{Characterization of High-Affinity Choline Uptake in CG and NC Cultures}

High-affinity choline uptake in cultures of CG neurons has already been extensively characterized (Barald and Berg, 1979b). Effects of antibodies on this uptake are discussed below.

In cultures of NC cells derived from mesencephalic neural crest at $31 \mathrm{hr}$ after incubation (Barald, 1982;
Barald, 1988), we examined HACU in cultures that contained both antigen-positive and antigen-negative cells and in subcultures of antigen-positive cells after antigennegative cells had been removed by laser ablation with an ACAS470 cytometer (see below; more extensive descriptions of the latter studies are submitted). The characteristics of the uptake system are seen in Table II. $\left[{ }^{3} \mathrm{H}\right]$ choline uptake was examined 3-7 days after culturing or subculturing the $\mathrm{NC}$ cells.

Uptake was linear for at least $10 \mathrm{~min}$ over a range of choline concentrations. We found, by double reciprocal analysis of the data (as in Barald and Berg, 1979a; Barald, submitted), a high-affinity sodium-dependent component with a $\mathrm{K}_{\mathrm{m}}$ of $0.5 \pm 0.08 \mu \mathrm{M}$ (number of determinations $=14$; number of cultures per time point, 3 ). The properties of choline uptake at $0.1 \mu \mathrm{M}$ were then examined to determine if the high-affinity uptake mechanism resembled those of chick ciliary ganglion neurons (Barald and Berg, 1979b). Uptake was blocked by $10 \mu \mathrm{M}$ hemicholinium-3 (HC-3) and by replacing the $\mathrm{Na}^{+}$with $\mathrm{Li}^{+}$(Table II). Eighty-three percent of the sodium-dependent uptake could be inhibited by $10 \mu \mathrm{M}$ HC-3.

However, because both antigen-positive and antigen-negative NC cells were present in the cultures and 

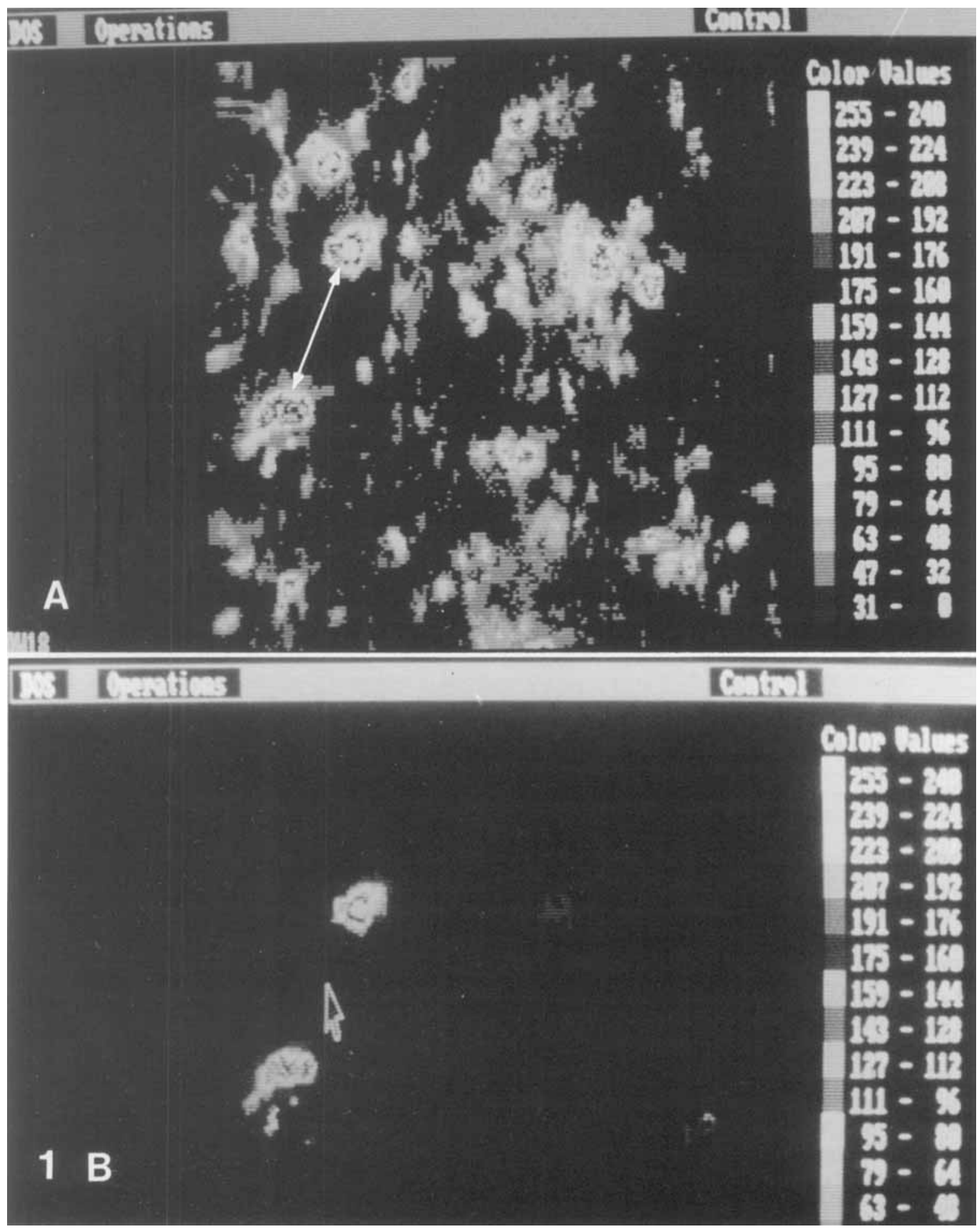

Fig. 1. A: False color images of a field of mesencephalic neural crest cells from 31-hr stage-9 chick embryos (seen here in black and white) are represented in this photograph of the CRT screen of the Meridian ACAS470 cytometer. The livecell culture was stained with fluorescein-conjugated concanavalin $\mathrm{A}$ (Con $\mathrm{A}$ ) at $6^{\circ} \mathrm{C}$ on the cooled stage (see Methods) and viewed with optics suitable for fluorescein. In this image all the cells in the dish are labeled, so that all are visualized in the CRT image. Note the two cells indicated by the double-headed arrow. B: The culture was also stained with Mab CG-14 (0.5 $\mu \mathrm{g} / \mathrm{ml})$ and a second-step rhodamine-conjugated rabbit antimouse antibody and visualized with optics suitable for rhodamine. Note that two of the cells in the culture are labeled (the two indicated above with the double-headed arrow). Laser ablation of the antigen-negative cells resulted in the two antigen-positive cells remaining alive at the end of the sort and the rest of the cells being killed by the radiant energy of the laser. 
TABLE II. High Affinity Choline Uptake in CG and NC Cultures ${ }^{* \dagger}$

\begin{tabular}{|c|c|c|c|c|}
\hline Cell type & $\begin{array}{c}\mathrm{HACU}^{\mathrm{a}} \\
\mathrm{K}_{\mathrm{n} 1} \\
(\mu \mathrm{M})\end{array}$ & $\begin{array}{c}\mathrm{LACU}^{\mathrm{b}} \\
\mathrm{K}_{\mathrm{m}} \\
(\mu \mathrm{M})\end{array}$ & $\begin{array}{l}\text { Inhibition by } \\
10 \mu \mathrm{M} \mathrm{HC}-3^{\mathrm{c}} \\
\text { (\% inhibition) }\end{array}$ & $\begin{array}{c}\text { Inhibition by } \\
\mathrm{Na}^{+} \text {deprivation } \\
\text { (\% inhibition) }\end{array}$ \\
\hline CG neurons & $0.3 \pm 0.1$ & $87 \pm 3$ & $83 \pm 3$ & $79 \pm 5$ \\
\hline NC (unsorted) & $0.6 \pm 0.2$ & $98 \pm 2$ & $68 \pm 8$ & $65 \pm 7$ \\
\hline \multicolumn{5}{|l|}{ NC (sorted) } \\
\hline $\mathrm{A}^{+\mathrm{e}}$ & $0.5 \pm 0.1$ & $103 \pm 8$ & $80 \pm 4$ & $82 \pm 3$ \\
\hline$A^{-f}$ & - & $86 \pm 4$ & $7.5 \pm 2$ & $3 \pm 1$ \\
\hline
\end{tabular}

${ }^{\text {a }}$ High-affinity choline uptake.

${ }^{\mathrm{b}}$ Low-affinity choline uptake.

${ }^{\mathrm{c}}$ Hemicholinium-3.

${ }^{\mathrm{d}}$ All sodium in the medium is replaced by lithium.

${ }^{\mathrm{e}}$ Antigen-positive NC population after sorting and laser ablation of the antigen-negative population.

${ }^{\mathrm{f}}$ Antigen-negative NC population after sorting and laser ablation of the antigen-positive population.

*All values are expressed as the mean \pm standard error of the mean $(n=3)$.

$\nmid$ High-affinity choline uptake is expressed as $p$ moles of choline taken up per $10^{4}$ neurons at a level of $0.1 \mu \mathrm{M}$ choline. Uptake was for $5 \mathrm{~min}$. The experiment was repeated four times, with three cultures contributing to each time point. Figures here are for $25 \mu \mathrm{g} / \mathrm{ml}$ of each antibody if the antibody was used alone. In the case of the combined antibodies: $25 \mu \mathrm{g} / \mathrm{ml}$ of CG-1 was combined with $3 \mu \mathrm{g} / \mathrm{ml}$ of CG-4 for 15 min before the determination of high-affinity choline uptake. The specific inhibitors, at concentrations specified previously, were preincubated with neuronal cell cultures for $1 \mathrm{hr}$. High-affinity choline uptake was assayed by our previously described methods.

the high-affinity component was small, with a small $\mathrm{V}_{\max }$, it was not possible to ascribe the high-affinity choline uptake seen in these cultures to the $\mathrm{A}^{+}$cells. We therefore ablated the antigen-positive cells with CG-1, CG-4, and complement (as detailed in the preceding paper, Barald, 1988; Barald, 1982) and found that after abolition of the antigen-positive cells, we could detect no sodiumdependent high-affinity choline uptake in the cultures at any time over a 2-week period (Table I), but a lowaffinity component was present. That is, after the cells were ablated, no other cells in the culture were found with HACU.

When the $\mathrm{A}^{+}$population, which was recovered after ACAS470 sorting, was recovered and subcultured, however, cells had both high- and low-affinity choline uptake components, with Michaelis constants (apparent $\mathrm{K}_{\mathrm{m}} \mathrm{s}$ ) of $0.5 \mu \mathrm{M}$ and $90 \mu \mathrm{M}$, respectively (Table I) (see next section).

\section{Isolation of the Antigen-Positive Neural Crest Subpopulation by No-Flow Cytometry}

In order to study the HACU in the antigen-positive NC population in more detail, we used the ACAS470 cytometer (Meridian Instruments, Okemos, MI) to ablate the antigen-negative NC population (Fig. 1) (see Methods). In our preliminary studies (Barald, 1983) we had separated antigen-positive and antigen-negative cells by flow cytometry with some success. However, loss of a large number of viable cells during and after the sort and the huge amount of starting material necessary for a single experiment (100 embryos) precluded routine use of flow cytometry for preparation of $\mathrm{A}^{+} \mathrm{NC}$ cultures. Therefore we acquired the ACAS 470 cytometer, an instrument that sorts cells from monolayers rather than from cell streams. We laser-ablated either the antigennegative or antigen-positive cells, passaged the remaining cells from ten dishes (prepared from NC from $25 \mathrm{em}-$ bryos), and examined $\mathrm{A}^{+}$and $\mathrm{A}^{-}$neural crest cultures (Barald, submitted).

Recoveries of cells after laser ablation of the unwanted population were good. We recovered $85-90 \%$ of the $\mathrm{A}^{+} \mathrm{NC}$ cells that could be passaged after trypsin treatment. However, we also found that in order to eliminate all of the antigen-negative cells from the $\mathrm{A}^{+}$population, we sometimes had to eliminate $\mathrm{A}^{+}$cells that were in proximity. We therefore plated fewer crests per dish; this decrease in cell density considerably helped the problem. Since cells are maintained under culture conditions during laser ablation (Schindler et al., 1985), sorting more dishes did not pose a problem for cell survival. Because cells can be grown under conditions that encourage proliferation of the antigen-positive cell population (Barald, submitted) without encouraging their differentiation, we can expand the population before inducing differentiation in the cultures with changes of medium (Barald, submitted). 
The growth characteristics in culture of antigenpositive NC cells were quite similar to those of the unsorted population recognized by the Mabs (Barald, 1988). Cell division times, amount of choline acetyltransferase (ChAT) activity, and the sensitivity of the HACU in these cultures to $\mathrm{HC}-3$ and $\mathrm{Na}^{+}$deprivation were the same as these characteristics in unsorted cultures.

\section{Effect of Antibody Treatment on High Affinity Choline Uptake of CG and NC Cultures}

When Mabs were added to cultures of either NC or CG neurons, they had specific, large effects on high affinity choline uptake (Table I, Figs. 2, 3).

CG Cultures. These studies were all done in the absence of complement. Neither CG-1 or CG-4 alone, even at high concentrations (5-10 $\mu \mathrm{g} / \mathrm{ml}$ and $25 \mu \mathrm{g} / \mathrm{ml}$ ), had an effect on HACU $\left(V_{\max }\right.$ or $\left.K_{m}\right)$ in cultures of 8day embryonic CG between days 2 and 14 in culture (the effect of CG-1 is illustrated in Fig. 2B). However, CG-1 and CG-4 in the absence of complement at ratios of $8 / 1$ ( $5 \mu \mathrm{g}$ of affinity-purified CG-1 and $0.6 \mu \mathrm{g}$ of CG-4) (see Barald, 1981, 1988) had a marked effect, inhibiting uptake by $40 \%$ (Fig. 2B). CG-14, the Mab made to mesencephalic NC cells, had a large inhibitory effect on HACU. After a $15-\mathrm{min}$ incubation in the Mab at $0.8 \mu \mathrm{g} / \mathrm{ml}, 87 \%$ of the uptake was inhibited, an amount of inhibition equivalent to or better than treatment with $10 \mu \mathrm{M}$ HC-3 for $15 \mathrm{~min}$ (Barald and Berg, 1979a) (Figs. 2,3).

NC Cultures. The effect of the antibodies on NC cultures made from AP cells isolated by no-flow cytometry was even more striking. The effects of the antibodies were examined over a wide range of concentrations. Only in the ratios in which they have cytotoxic effects do CG-1 and CG-4 affect the uptake. For the sake of clarity, only one such concentration ratio for each cell type is illustrated in Figure 2. Although neither CG-1 nor CG-4 alone (CG-1 is illustrated in Fig. 2A) inhibited HACU at all, the two monoclonal antibodies in concert inhibited $75 \%$ of the HACU at the same concentrations used to inhibit uptake in CG cultures. CG-14 at $0.6 \mu \mathrm{g} / \mathrm{ml}$ inhibited $80 \%$ of the HACU, an effect equivalent to that seen for $10 \mu \mathrm{M}$ HC-3 (Fig. 2A). Addition of CG-1 and/or CG-4 to CG-14 did not enhance the effect in either NC or CG cultures (data not shown).

\section{Spinal Cord Cultures}

Spinal cord neurons in culture also have a highaffinity choline uptake mechanism (Barald and Berg, 1978, 1979a), with a Michaelis constant of around $3 \mu \mathrm{M}$. This uptake too is HC-3-sensitive and sodium-dependent (Barald and Berg, 1978). However, in the absence of complement, the CG-1/CG-4 pair or treatment with each

\section{A}

Mab Effects on HACU in Neural Crest Cultures

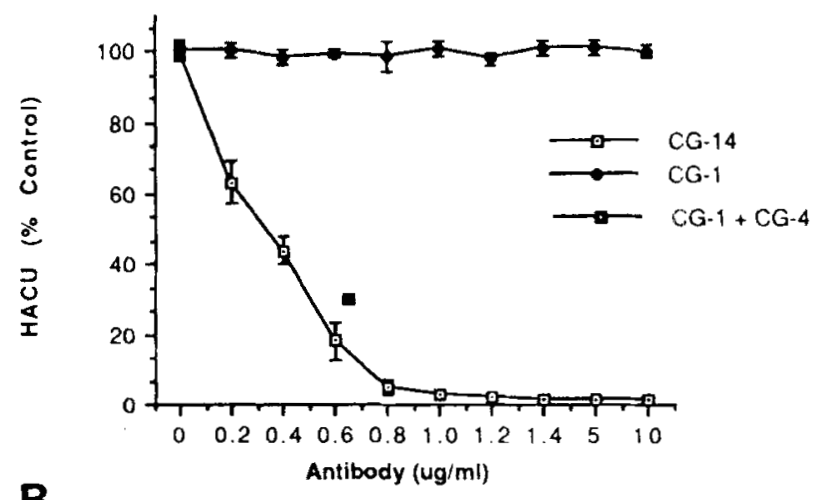

Effects of Mabs on HACU in CG Cultures

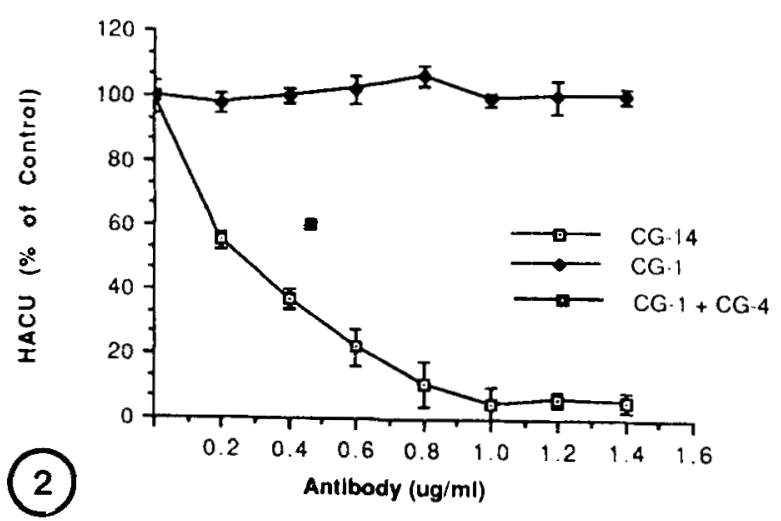

Fig. 2. High-affinity choline uptake was measured at $0.1 \mu \mathrm{M}$ choline as described in Methods in (a) 31-hr neural crest cultures isolated by ACAS 470 cytometry after 5 days in culture and (b) 8-day ciliary ganglion neuron cultures after 5 days in culture. The medium was composed of $10 \%$ chick serum in ovotransferrin-containing basic medium without $\mathrm{KCl}$ (see Barald, 1988). A: Increasing concentrations of CG-1 alone ( have no effect on the HACU in NC cultures made from subcultured ACAS-selected cells (control levels: $0.2 p$ $\mathrm{mole} / \mathrm{min} / \mathrm{mg}$ protein), even up to $25 \mu \mathrm{g} / \mathrm{ml}$ (not shown). A similar result was found for CG-4 alone. When CG-1 and CG4 are combined $(5 \mu \mathrm{g} / \mathrm{ml} \mathrm{CG}-1$ and $0.6 \mu \mathrm{g} / \mathrm{ml} \mathrm{CG}-4)$ in the absence of complement, however, $75 \%$ of the HACU is inhib-

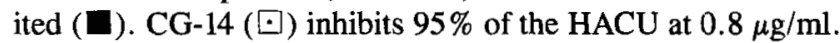
B: In CG neuron cultures (control levels of uptake at $0.1 \mu \mathrm{M}$ : $3.6 \mathrm{pmole} / \mathrm{min} / \mathrm{mg}$ protein), similar effects are seen. Neither CG-1 (shown here) nor CG-4 (not shown) has any effect on HACU in neuron cultures, even at high concentrations. CG-1 and CG-4 (in the same concentrations used in A for NC cells) inhibit $40 \%$ of the uptake. However, CG-14 at $1.0 \mu \mathrm{g} / \mathrm{ml}$ inhibits $95 \%$ of the uptake.

antibody singly had no effect on the uptake. CG-14 had a slight effect, inhibiting the uptake by $10 \%( \pm 2$, SEM, $\mathrm{n}=5$ ). 
A Ouabain Binding to CG Neurons

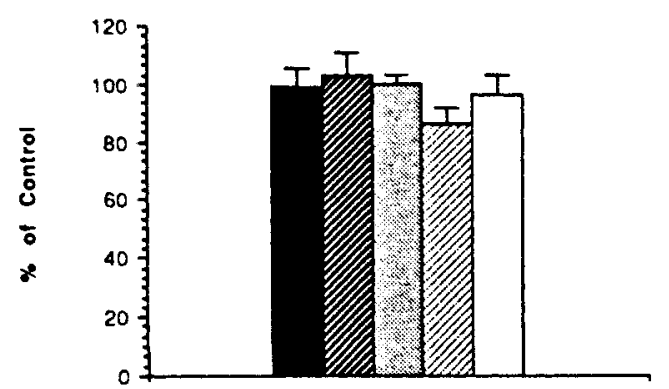

C High Affinity Choline Uptake Vmax in CG Neurons

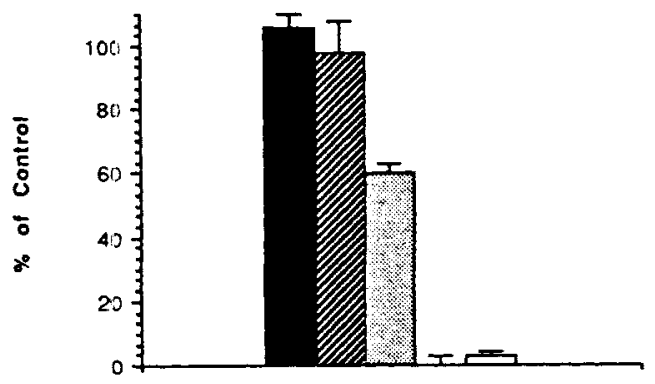

B Ouabain binding to Isolated Neural Crest Cells

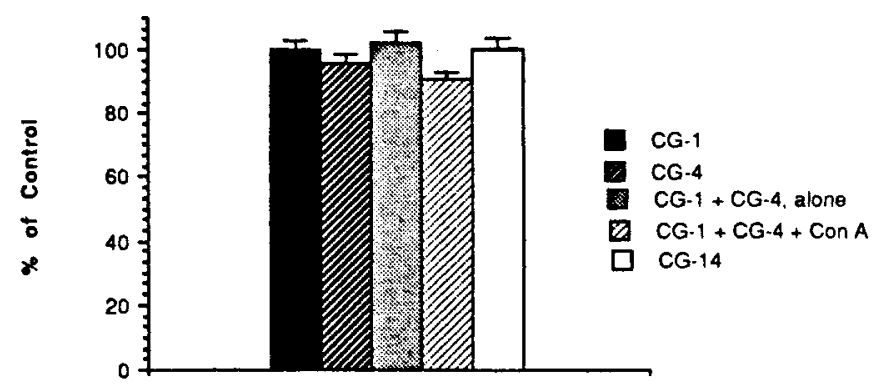

D High Affinity Choline Uptake Vmax in Isolated NC Cells

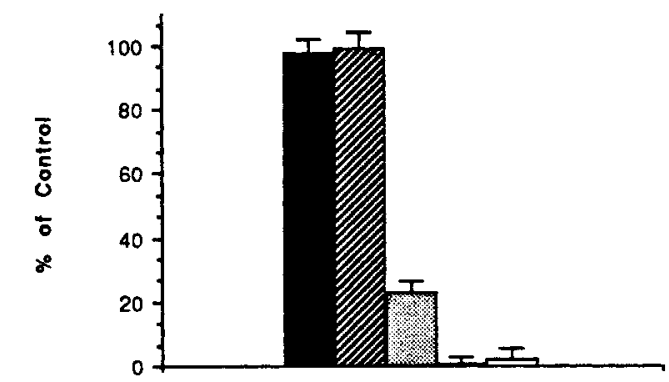

E Low Aftinity Choline Uptake Vmax in CG Neurons

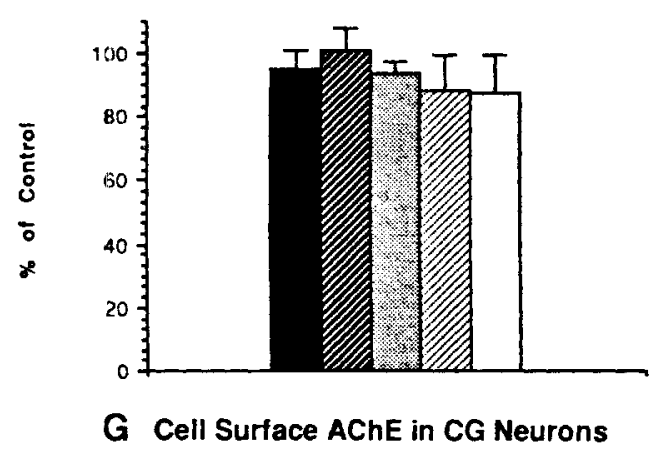

F Low Affinity Choline Uptake Vmax in Isolated NC Cells
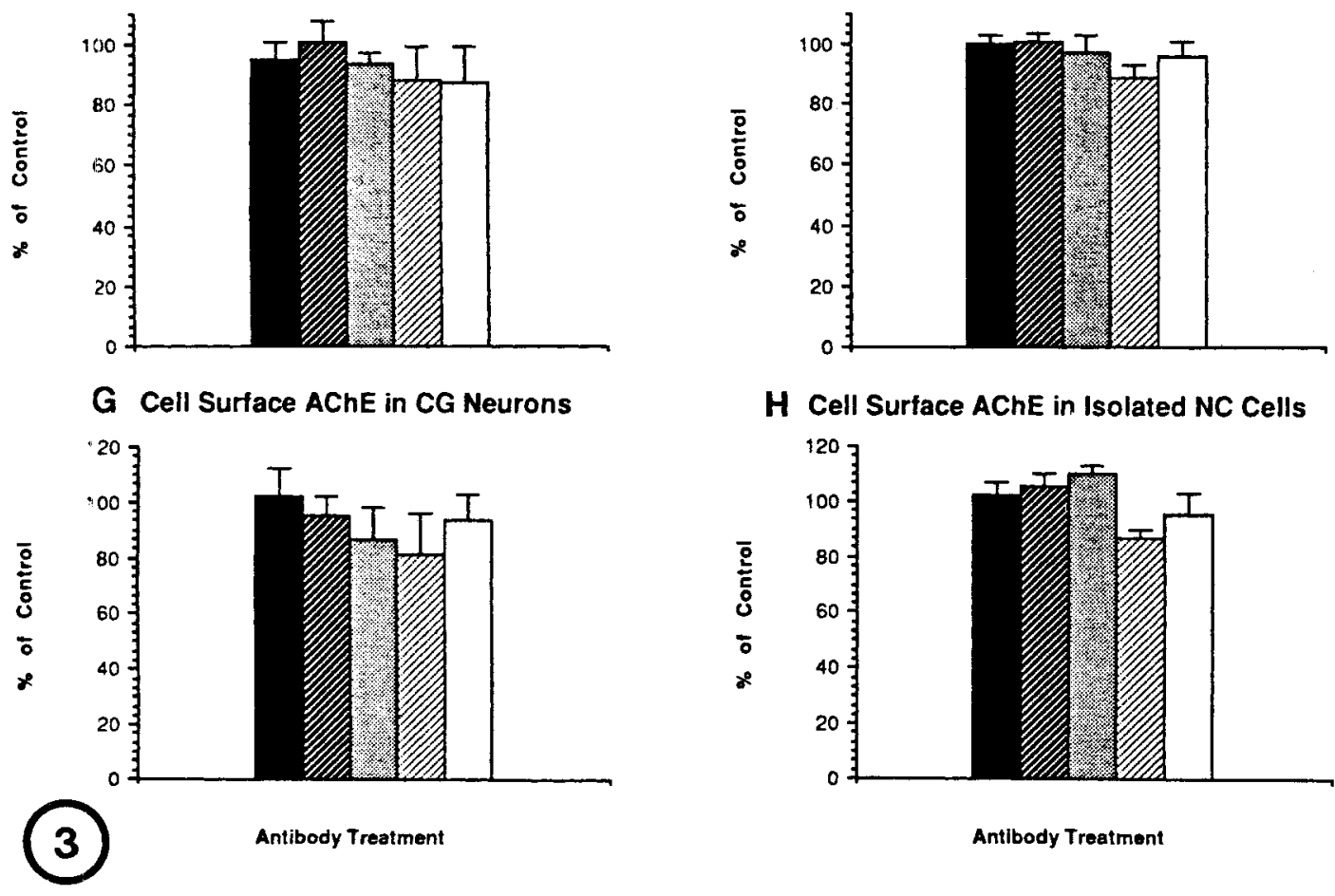

H Cell Surface AChE in Isolated NC Cells

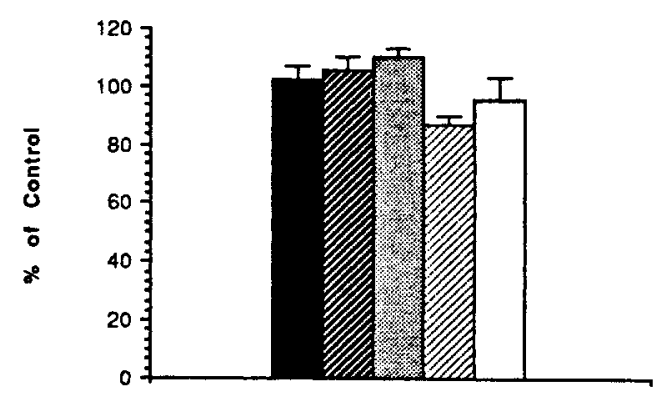

Antibody Treatment

Fig. 3. In the absence of complement, effects of the monoclonal antibodies CG-1 $(5 \mu \mathrm{g} / \mathrm{ml})$ (black), CG-4 $(5 \mu \mathrm{g} / \mathrm{ml})$ (dark stripe), CG-1 + CG-4 $(5 \mu \mathrm{g} / \mathrm{ml} / 0.6 \mu \mathrm{g} / \mathrm{ml})$ in the presence (light stripe) and absence (grey) of concanavalin $\mathrm{A}$ and CG-14 (1. $\mu \mathrm{g} / \mathrm{ml})$ (white) were examined on cell-surface-associated parameters of CG neurons (left) and NC cells (right). Cultures were prepared as described in the legend to Figure 2 (three cultures per condition were used; the experiment was repeated twice). A range of concentrations of the antibodies was initially tried. The concentrations selected for the experiment are based upon the experiment illustrated in Figure 2. Parameters A-H were examined. A,B: Ouabain binding was

measured under saturating conditions in the cultures as described in Methods (c.f., Hootman and Ernst, 1988) and the results are expressed as a percentage of the control binding. The level of radioactivity/culture in control CG cultures (no antibody) was $8,100 \mathrm{cpm} / \mathrm{mg}$ protein and in NC cultures it was $1,680 \mathrm{cpm} / \mathrm{mg}$ protein. C,D: High-affinity choline uptake was determined as in the experiment described in Figure 2. Note the profound effect of the Mabs with and without Con A on the magnitude of the uptake. E,F: Effect of the monoclonals on low-affinity choline uptake in these cultures was minimal. G,H: Again, the effect of antibody binding on cell surface AChE was not significantly different from controls. 


\section{Effect of the Mabs on Other Cell Surface Components in CG and NC Cells}

In order to determine whether the effect of the Mabs on HACU in CG neuron cultures and cultures of NC cells was specific, we examined three other cellsurface-associated parameters of cells: low-affinity choline uptake; ouabain-binding sites, as a measure of $\mathrm{Na}^{+} \mathrm{K}^{+}$ATPase (Hootman and Ernst, 1988); and the presence and activity of AChE (see Methods). None of the Mabs alone or in combination affected these parameters to any great extent, even when Con A was used to internalize the antibody binding sites of CG-1 and CG-4 in the absence of complement (see Fig. 3). The three control parameters were measured in cultures of both CG and NC cells within half an hour of internalization of the antibody binding sites, well before restoration of the antigen in the cell membrane and at times when HACU was completely abolished. These parameters illustrate, as demonstrated by others (Meyer, 1986, 1987), that the high- and low-affinity choline uptake mechanisms are completely separable and affected by different conditions. Ouabain binding sites reflect the $\mathrm{Na}^{+} \mathrm{K}^{+}$ATPase, a cell surface membrane marker of many different types of cells (reviewed in Hootman and Ernst, 1988). There has been at least one report that AChE might in some way be linked to HACU sites on presynaptic terminals (Raiteri et al., 1986), so it was reasonable to investigate this marker. However, it too was unaffected.

\section{Treatment of CG-1- and CG-4-Labeled Cultures With Concanavalin A}

In early experiments in which we demonstrated that the monoclonal antibodies could differentiate between CG neurons and other neuronal cells derived from the neural crest, such as dorsal root ganglion neurons, we mixed the two cell types in culture in specific ratios in order to determine whether the neurons could be distinguished from one another. We used fluorescein-conjugated concanavalin A to label all the cells in the cultures for ease of counting in the fluorescence scope. We labeled these mixed live cell cultures with the CG-1 and CG-4 monoclonals concomitantly (both of which are of the IgG gamma 2a subclass) and then treated the cultures with an antibody to mouse IgG conjugated with rhodamine. A typical experiment of this type is illustrated in Figure 4. We mixed CG neurons and dorsal root ganglion neurons together in culture in ratios of $1 / 10$ and labeled the cultures with both fluorescein-conjugated-Con A and with the monoclonal antibodies.

When we did these experiments, we found that if the labeling was done at room temperature in the presence of Con A, the antibody, not surprisingly, became internalized in the cells that they labeled, giving us a nice marker for the labeled cells (Fig. 4). This did not occur in the presence of wheat germ agglutinin (data not shown).

When the antibodies became internalized, we also saw a marked effect on the HACU, which was abolished in these treated cultures (see Fig. 3). However, the lowaffinity sodium-independent uptake was essentially unchanged (Fig. 3). Thus, Con-A-mediated internalization of the antibodies can be used both to mark the labeled cells and to eliminate the HACU without affecting any of the other cell surface parameters appreciably (see Fig. 3 ). This further illustrates that the antibody effects are specific and not effecting general membrane perturbations.

\section{Restoration of Antibody Binding Sites After Trypsin Treatment}

Because we trypsin-treat NC cell cultures for subculturing and cell sorting experiments, it was necessary to determine how long it takes for antibody-binding sites to be reinstated after trypsin treatment. If either CG neurons or NC cells were treated with trypsin, and iodinated protein $\mathrm{A}$ used to determine how quickly the antibody-binding sites were reinserted in the membrane, we found that $4 \mathrm{hr}$ were required for the restoration of antibody-binding sites on both CG neurons and NC cells. Restoration of Mab binding sites on NC cells is illustrated in Figure 5. Subsequent autoradiography confirmed that the binding was on the cell surface of live (confirmed by ethidium bromide and acridine orange staining) neurons and not internal (data not shown). When similar experiments were repeated on NC cells at 8 days in culture, restoration of CG-1 or CG-14 antibody binding sites also took $4 \mathrm{hr}$, with similar kinetics. Restoration of CG-1 antibody-binding sites after trypsin treatment of $\mathrm{NC}$ cells is illustrated in Figure 5. We were able to follow the binding both by filtration assay and by autoradiography of the cultures to determine whether the same percentage of cells restored antibody binding sites as usually labeled with the antibody in the cultures; we found that $5 \%$ of NC cells in cultures of mixed antigen-positive and antigen-negative cells restored antibody binding sites. We did not see large numbers of antibody binding sites appearing on only a few cells, which would have indicated that not all cells that initially bore the antigen restored it to their cell surfaces during this time period (fewer than the 5\% that usually label). Neither was a low level of antibody binding seen in all or most cells in NC cultures. Only $5 \%$ of the cells in culture reacquired antibodybinding sites. When we repeated the experiments qualitatively with fluorescently labeled antibodies, we found similar results (data not shown).

CG-14 antibody binding sites had similar restoration kinetics. When we examined the restored antibody binding sites electrophoretically by isolating cell mem- 

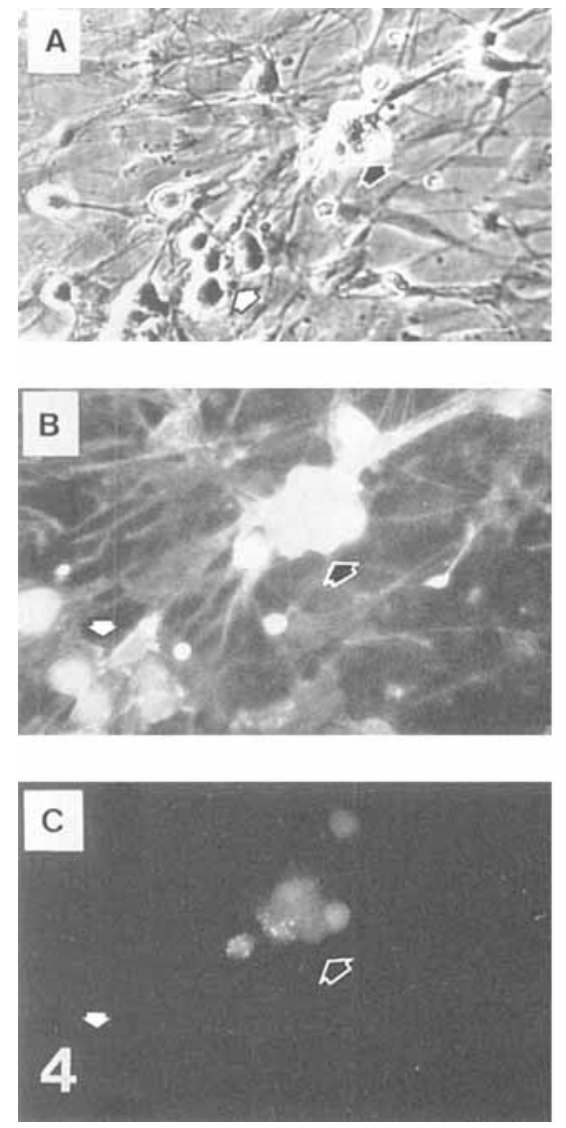

Fig. 4. Interralization of monoclonal antibodies CG-1 and CG4 by concanavalin A. Fluorescein-labeled Con A (Vector) and CG-1 $(5 \mu \mathrm{g} / \mathrm{ml})$ and CG-4 $(0.6 \mu \mathrm{g} / \mathrm{ml})$, which were labeled with a second-step rhodamine-conjugated antibody, were used to label combined cultures of ciliary ganglion neurons (CG) from 8-day embryonic chick and 10-day embryonic dorsal root ganglion neurons (DRG), which were plated in the cultures at ratios of ten DRGs for every $1 \mathrm{CG}$ neuron. In $\mathbf{A}$ and $\mathbf{D}$ two different fields of such cultures from two separate dishes are examined by phase contrast microscopy. Neuronal somas are about $30 \mu \mathrm{m}$ in diameter. Black arrows indicate a group of presumptive ciliary ganglion neurons. White arrows indicate a group of presumptive DRGs. In $\mathbf{B}$ and $\mathbf{E}$, viewed with
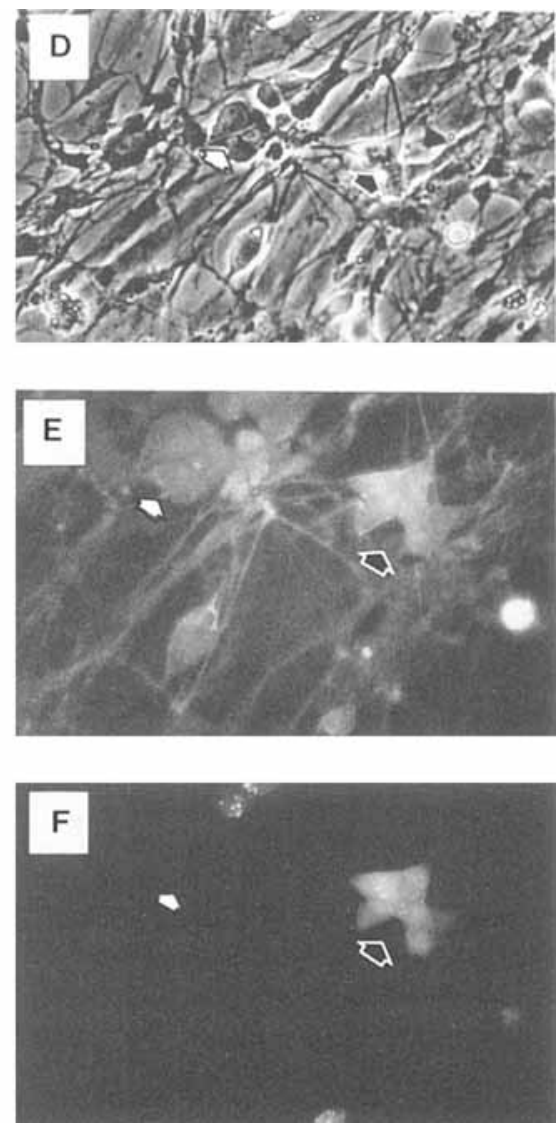

fluorescein optics to look at Con A fluorescence, all of the neurons in the culture are visible (as well as some nonneuronal ganglionic cells). Con A labels the cells indiscriminately. Again the black arrows indicate presumptive CG neurons and the white arrows presumptive DRGs. In $\mathbf{C}$ and $\mathbf{F}$, viewed with rhodamine optics, the ciliary ganglion neurons are indicated by black arrows and have both external uniform cell surface fluorescence and internal dots of antibody fluorescence. Note the cells indicated by the white arrows in $\mathbf{B}$ and $\mathbf{E}$ that are missing in $\mathbf{C}$ and $\mathbf{F}$. Internal spots of bright fluorescence are not seen in every neuronal soma since internal fluorescent patches are in focus in only one plane. branes and separating them on denaturing polyacrylamide gels, which were then Western blotted (see the preceding paper, Barald, 1988), the $75-\mathrm{kD}$ antigen band was resiored before the appearance of the $82-\mathrm{kD}, 53-\mathrm{kD}$, and $46-\mathrm{kI}$ ) bands (Barald and Wolff, in preparation). These experiments demonstrate that the antibodies bind to cell surface determinants, which are replaced with similar kinetics after trypsin treatment.

\section{DISCUSSION Summary of Results}

The studies presented here demonstrate several points.

1. A high-affinity choline uptake mechanism is present in antigen-positive neural crest cells and has an apparent Michaelis constant $\left(\mathrm{K}_{\mathrm{m}}\right)$ of $0.5 \mu \mathrm{M}$, which is very close to that which we have already determined for 
Antibody Binding to Dissociated NC Cells in vitro

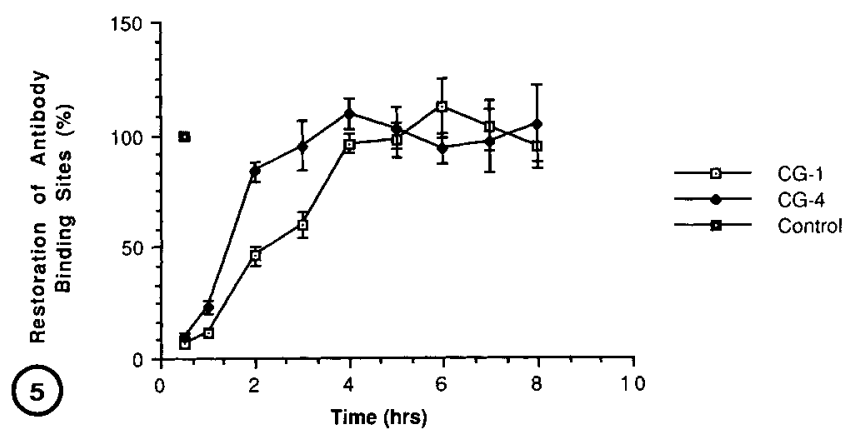

Fig. 5. ${ }^{125} \mathrm{I}$ protein $\mathrm{A}$ was used to determine the amount of binding of antibodies CG-1 and CG-4 $(5 \mu \mathrm{g} / \mathrm{ml})$ to dissociated mesencephalic neural crest cells from stage- 9 embryos prepared as described in the legend to Figure 2. Binding to control cultures (single closed square) was determined by applying the antibody for $1 \mathrm{hr}$ with subsequent careful washing and then application of the ${ }^{125} \mathrm{I}$ protein $\mathrm{A}$ for $30 \mathrm{~min}$. Three cultures were used for each time point, and specific activities of amount of binding/total protein were determined in each case. In experimental cultures, trypsin treatment was carried out by exposing the cultures to $0.25 \%$ GIBCO trypsin in Puck's saline with glucose but without additional cations for 4-11 min. The trypsinization was stopped either by the addition of medium containing chick serum or by addition of medium containing soybean trypsin inhibitor (Sigma). Conditions were optimized for removal of antibody binding components from cells. By varying the length of the recovery period, it was possible to get an estimation of the time required for the reinsertion of sites. Antibody binding is expressed as a percentage of the radioactivity (determined by gamma counting) in control cultures labeled with ${ }^{125} \mathrm{I}$ protein $\mathrm{A}$. In a parallel series of experiments, autoradiography was used to detect the numbers of cells that bound the protein $A$ under each condition. Results of the two types of experiments were comparable (not shown).

CG neurons: $0.3 \mu \mathrm{M}$ (Barald and Berg, 1979b). The HACU is sodium-dependent and sensitive to $10 \mu \mathrm{M} \mathrm{HC}$ 3 , which inhibits it by $83 \%$. Thus, it bears characteristics common to HACU of a wide range of cholinergic neurons from both central and peripheral sources.

2. This HACU in both unsorted and ACAS-isolated antigen-positive NC cells is highly sensitive to the combined Mabs CG-1 and CG-4 in the absence of complement. The two Mabs, in ratios of 8/1 (5 $\mu \mathrm{g} \mathrm{CG-1} \mathrm{and}$ $0.6 \mu \mathrm{g} \mathrm{CG}-4$ ) inhibit the HACU by $75 \%$ (Fig. 2 ).

3. Mab CG-14 alone, in the absence of complement has an even more striking effect; at $1 \mu \mathrm{g} / \mathrm{ml}$, it inhibits $95 \%$ of the HACU, sparing the LACU, ouabain-binding sites and AChE on the cell surface.

4. While Mabs CG-1 and CG-4 together in appropriate ratios, but in the absence of complement, affect the HACU of CG neurons by only $40 \%$ (see Fig. 2) and neither antibody alone has any effect on HACU, CG-14 alone affects the HACU in these cells by $95 \%$.

5. Neither Mab CG-14 nor Mabs CG-1 and CG-4 in the absence of complement or in the presence of Con A affects three other cell surface parameters: low-affinity choline uptake, ouabain binding, or AChE. None of the Mabs (in the absence of complement) affects other cell characteristics, including protein levels, LDH activity, and general morphology (Table I). Block of HACU by CG-14 in ciliary neurons, while not affecting the formation of nerve contacts on skeletal muscle cells in culture, subsequently affects synaptogenesis (Barald and Wolff, in preparation). However, none of these antibodies affects the low-affinity (sodium-independent) choline uptake mechanism of the CG neurons or NC cells.

\section{The Antibodies Do Not Affect Other Cell Surface Components, Growth, or Cell Function}

The finding that the antibodies do not affect other cell surface or internal cellular functions, including cell division and general morphology of CG neurons and NC cells, demonstrates that the antibodies are not having any nonspecific deleterious effects on the cells' health. All the cells in the cultures are viable (by ethidium bromide and acridine orange staining; Table I). The fact that AChE is also unaffected is important because of a report by Raiteri et al. (1986), which demonstrated that the HACU transporter and AChE are apparently in close proximity to one another on rat cortical synaptosomes. They suggest that the HACU transport mechanism and AChE may be somehow coupled. However, if the two are coupled, the coupling mechanism cannot be direct in these cells, because we have found that abolition of the HACU by the Mabs leaves AChE unaffected.

\section{Antiubiquitin Antibodies Also Inhibit HACU}

The finding by Meyer et al. (1986, 1987) that a polyclonal antibody to ubiquitin specifically inhibits the high- but not the low-affinity choline uptake mechanism of rat brain synaptosomes $(10 \mu \mathrm{g} / \mathrm{ml}$ for $60 \mathrm{~min}$ inhibited $95 \%$ of the HACU) is intriguing. Ubiquitin is a 76 aa residue heat shock protein, which is among the most highly conserved proteins found in higher organisms (Hershko and Ciechanover, 1982; Hershko, 1983). It is involved in general posttranslational modifications of cellular proteins in which its C-terminal carboxyl is covalently linked to an amino group of an acceptor protein (see Hershko, 1983). Because ubiquitin has a large and diverse repertoire of acceptor proteins, this posttranslational modification scheme may serve many different cellular functions, depending on the function of the acceptor protein and the ubiquitin-acceptor protein complex (Hershko, 1983).

Meyer et al. (1987) also reported that their rabbit antiubiquitin polyclonal antibody also inhibited other so- 
dium-dependent transport mechanisms for norepinephrine, aspartate, serotonin, gamma-amino butyric acid (GABA), and glutamate in rat cerebral cortical synaptosomes at $10 \mu \mathrm{g} / \mathrm{ml}$. It also affected the uptake of deoxyglucose in glucose-free medium, but other sodiumdependent transport processes were unaffected. This result suggests a general mechanism of ubiquitination of neuronal transport sites. Furthermore, their study suggests that ubiquitin binds to extracellular sites on the HACU and other sodium-dependent neuronal transporters or to a proximal site.

\section{Mabs CG-1, CG-4 and CG-14 Are Probably Not Recognizing Ubiquitin}

While we have not ruled out the possibility that CG-1, CG-4, and CG-14 bind to ubiquitin itself, we think this is unlikely for the following reasons.

1. Our antibodies do not bind to other cell types besides NC and CG cells. Since ubiquitin presumably binds to many external acceptor proteins, including the other neuronal transporters present on adrenergic cells, the GABA binding sites on GABA-ergic neurons in the spinal cord as well as the lymphocyte homing receptor (MEL-14) (Siegleman et al., 1986) and a platelet-derived growth factor receptor (Yarden et al., 1986), one would expect that our antibody would recognize a more widely distributed determinant. Our antibodies do not recognize any binding sites on lymphocytes (Barald and Wolff, unpublished) or other neuronal cell types that would be expected to have transport mechanisms either for choline or for other neurotransmitters. Although the CG-14 Mab inhibits HACU in spinal cord neuron cultures by $10 \%$, we have not been able to demonstrate fluorescently labeled Mab binding to any neurons in chick or quail SC from 3 to 10 day embryos over a 2-week period in culture. We are presently repeating these studies with radiolabeled antibodies to determine if our previous methods are sufficiently sensitive.

2. Our antibodies have no effect on GABA uptake (Barald, unpublished); if the antibodies are to ubiquitin, one would expect that they might affect GABA uptake in spinal cord cultures (see Barald and Berg, 1979a), since ubiquitin also binds to the GABA receptor and Meyer et al. (1987) have reported that antiubiquitin antibodies inhibit this uptake as well. We must now try to obtain an antibody to ubiquitin for binding and blocking studies with our antibodies and to determine whether ubiquitin antibodies at low concentrations have synergistic effects with our antibodies on HACU. This should solve the question of ubiquitin cross-reactivity with our antibodies.

However, another possibility that we cannot presently rule out is that our antibodies recognize some aspect of the covalent link between ubiquitin and a high-affinity choline transporter on CG neurons and NC cells. The transporter may have a unique sequence or configuration on CG neurons and on the population of NC cells (which could be CG precursors), and this pattern could be sufficiently different from the HACU transporter on spinal cord motoneurons or other neurons with a high-affinity choline uptake mechanism that the antibodies do not recognize the other transporters. We may also be able to explain the binding of CG-1 to the $82-\mathrm{kD}$ band on Westerns and the binding of CG-4 to the 53- and 46-kD bands (Barald, 1988). It is possible that these bands represent different ubiquitin-modified acceptors uniquely recognized by antibodies CG-1 or CG-4. However, we believe this scenario is unlikely for the same reasons cited to explain why we do not think that our antibodies are to ubiquitin itself.

\section{Do the Mabs Recognize the HACU Transporter?}

Our present working hypothesis is that our antibodies recognize a unique or uniquely configured HACU transporter on the surface of CG neurons, which also happens to be present on the NC antigen-positive subpopulation before they develop into neurons. The presence of a high-affinity choline uptake mechanism that is specifically blockable by the Mabs may be evidence of yet another cholinergic trait found in early migratory $\mathrm{NC}$ cells (Smith et al., 1979; Fauquet et al., 1981). The antigen-negative $\mathrm{NC}$ population does not have the HACU mechanism, and it also has no ChAT activity (Barald, submitted). This indicates that the residual populations of NC cells do not share cholinergic traits that may be found in both embryonic (Barald and Berg, 1978, 1979a,b) and mature (Yamamura and Snyder, 1972; Manaker et al., 1986) cholinergic neurons at early times. Kotas and Prince (1987) have recently reported that not all $\mathrm{HC}-3$ blockable high-affinity choline uptake in developing rat brain was into cholinergic neurons; however, their study did not show which cells were responsible for the uptake.

A number of years ago, Smith et al. (1979) demonstrated that as soon as cells in the mesencephalic crest began to migrate, they expressed choline acetyltransferase (ChAT) activity, and in addition, at least some of the cells had acetylcholinesterase activity (Cochard and Coltey, 1983). The cells that have ChAT activity and synthesize ACh were not, at the time, identified as individual cells, and it was not possible to determine what proportion of the cells had these characteristics. Subsequent studies by Sieber-Blum and Kahn (1982) and by LeDouarin's group (Ziller et al., 1983; Ziller, 1986; Ziller et al., 1987) demonstrated that culture conditions played a large role in cholinergic expression in NC cells. It should be noted that culture conditions also have a pro- 
found effect on cholinergic development of both $C G$ neurons (Teitelman et al., 1985) and other neurons as well, indicating that such expression is to some extent plastic (Nishi and Berg, 1981a,b; Iacovitti et al., 1987). Matsuoka et al. (1986) found that cholinergic differentiation of rat pheochromocytoma cells was influenced by conditioned medium from glioma cells. Mykita et al. (1987) found that high potassium (depolarization) increased the amount of choline uptake by the high-affinity mechanism in neuronal cells in culture. Rauca et al. (1985) found a similar result in slices of rat hippocampus. Since we have found that high potassium levels encourage differentiation of the NC subpopulation that can be identified with Mabs (Barald, submitted), it is possible that such differentiation is based on a physiological "feedback" loop that promotes the development of the HACU system along with a neuronal morphology.

We have confirmed the finding that culture environmental changes have striking effects on cholinergic differentiation of NC cells (Barald, 1982; Barald, submitted) and extended them to demonstrate which cells in the culture are responsible for both ChAT activity and the HACU (Barald, submitted).

\section{Significance of This Finding for Studies of Crest Lineages}

The antigen on the NC cells appears to be the same as that on the CG neurons, and in both cell types, it appears to be involved in the HACU. We have used both the CG-generated Mabs, CG-1 and CG-4, and the NCgenerated Mab, CG-14, to perturb the HACU in the NC cells as soon as these cells can be isolated from the $31 \mathrm{hr}$ neural crest. These determinations were made within 6 $\mathrm{hr}$ of $\mathrm{NC}$ removal from the embryo, indicating that the HACU is not a culture artifact but is present in these cells from very early times. The antigen is present on cells in the embryo at stage 9 (Barald and Wolff, in preparation) and can be used to isolate the cells by no-flow cytometry, demonstrating that the antigen on the NC cells does not arise in culture as a result of maturation of the cells, presumably into CG neurons. CG ganglion condensation takes place about day 2.5-3, and some neurons either have been born or begin to be born about this time (Noden, 1978; D'Amico-Martel, 1982). The antigen is present on NC cells as early as $31 \mathrm{hr}$ of incubation and persists on the cells through their maturation to cells that resemble neurons (Barald and Wolff, in preparation; Barald, submitted).

Although some cells in the neural crest may be pluripotent (see Anderson and Axel, 1986), it is clear from our work and that of many other investigators (Barald, 1982; Barald, and Wessells, 1984; Barald, 1987; Ciment and Weston, 1982, 1985; Vincent et al., 1983; Marusich et al., 1986; Barbu et al., 1986; Ziller et al.,
1987; Weston et al., 1988) that early differentiation of subpopulations of crest cells that may be destined to become neurons begins very early, considerably in advance of the time when migration is complete and before the acquisition of neuronal morphologies. Discovery of a neural crest subpopulation with cholinergic properties very similar to those of the embryonic CG neurons that they may become is a step toward discovery of the conditions that promote neuronal development and maturation. We are presently using the Mabs described in these studies to trace the lineage and descendents of the antigen-positive NC subpopulation.

\section{ACKNOWLEDGMENTS}

This work was supported by a grant from the National Science Foundation PCM 17271 to K.F.B. as well as USPHS grants NS17262 and NSI7017 to K.F.B. K.F.B. was also the recipient of grants from the Muscular Dystrophy Association of America and the Dysautonomia Foundation and of a Faculty Recognition Award from the University of Michigan. I would like to thank Laurie Polacek, Tami Hill, Dagmar Wolff, and Cindy Lam for excellent technical assistance. I would like to thank Kathryn Tosney, Carol Erickson, Gary Ciment, James Weston, Drew Noden, and Gerry Maxwell for many helpful and enjoyable discussions during the course of this work.

\section{REFERENCES}

Anderson DJ, Axel RA (1986): Bipotential neuroendocrine precursor whose choice of cell fate is determined by NGF and glucocorticoids. Cell 47:1079-1090.

Ansell GB, Spanner S (1967): The metabolism of labelled ethanolamine in the brain of the rat in vivo. J Neurochem 14:873885.

Barald, KF (1974): Distribution and characterization of cholinesterases in cultured chick embryo fibroblasts and in fibroblasts transformed by oncogenic RNA viruses. (PhD thesis, University of Wisconsin, Madison).

Barald, KF (1981): Cell surface specific monoclonal antibodies to chick ciliary ganglion neurons. Soc Neurosci Abs 7:129.

Barald, KF (1983): Monoclonal antibodies to chick ciliary ganglion isolate a neural crest subpopulation by fluorescence activated cell sorting. Soc Neurosci Abs 9:342.

Barald KF (1982): Monoclonal antibodies to embryonic neurons: Cell-specific markers for chick ciliary ganglion. In Spitzer NC (ed): “Neuronal Development." New York: Plenum, pp 101119.

Barald KF, Berg DK (1978): High affinity choline uptake by spinal cord neurons in dissociated cell culture. Dev Biol 65:90-99.

Barald KF, Berg DK (1979): Autoradiographic labeling of spinal cord neurons with high affinity choline uptake in cell culture. Dev Biol 72:1-14.

Barald KF, Berg DK (1979): Ciliary ganglion neurons in cell culture: High affinity choline uptake and autoradiographic choline labeling. Dev Biol 72:15-23.

Barald KF, Wessells NK (1984): Differential antigen adhesivity used to select spleen cells for the production of monoclonal antibod- 
ies to embryonic neurons. J Immunol Methods 73:1-15.

Barald KF (1987): Purification of antigen-specific B cells by adherence to whole cell antigens. In: Pretlow TG, Pretlow TP (eds): "Cell Separation: Methods and Selected Applications," Vol. 5. San Diego: Academic Press, Inc., pp 98-102.

Barald KF (1988): Monoclonal antibodies made to chick mesencephalic neural crest cells or to ciliary ganglion neurons identify a common antigen on the neurons and a neural crest subpopulation. J Neurosci Res 21:107-118.

Barbu M, Ziller C, Rong PM, LeDourain NM (1986): Heterogeneity in migrating neural crest cells revealed by a monoclonal antibody. J Neurosci 6:2215-2225.

Baughman RW, Bader CR (1977): Biochemical characterization and cellular localization of the cholinergic system in the chicken retina. Brain Res 138:469-485.

Bremer J. Greenberg DM (1961): Methyltransfering enzyme system of mizrosomes in the biosynthesis of lecithin (phosphatidylcholine). Biochim Biophys Acta 46:205-216.

Browning ET, Schulman MP (1968): $\left[{ }^{14} \mathrm{C}\right]$ Acetylcholine synthesis by cortex slices of rat brain. J Neurochem 15:1391-1405.

Ciment G, Weston JA (1982): Early appearance in neural crest and crest-derived cells of an antigenic determinant present in avian neurons Dev Biol 93:355-367.

Ciment G, Weston JA (1985): Segregation of developmental abilities in neural-crest derived cells: Identification of partially restricted intermediate cell types in the branchial arches of avian embryos. Devel Biol 111:73-83.

Cochard P. Coltey P (1983): Cholinergic traits in the neural crest: acetylcholinesterase in crest cells of the chick embryo. Dev Biol 98:221-238.

D'Amico-Manel A (1982): Temporal patterns of neurogenesis in avian cranial sensory and autonomic ganglia. Am $\mathbf{J}$ Anat 163:351-372.

Ellman GL, Courtney KD, Andres V, Featherstone RM (1961): A new and rapid colorimetric determination of acetylcholinesterase activity. Biochem Pharmacol 7:88-95.

Glanville NT, Cook HW, Spence MW (1987): Compartmentation of phosphorylated precursors of phospholipid biosynthesis in cultured neuroblastoma cells. Biochim Biophys Acta 904:392400 .

Greenberg JH. Schrier BK (1977): Development of choline acetyltransferase activity in chick cranial neural crest cells in culture. Dev Biol 61:86-93.

Groth DP, Bain LA, Pfeiffer CC (1958): The comparative distribution of $\mathrm{C}^{14}$-labeled 2-dimethylaminoethanol and choline in the mouse. J Pharmacol Exp Ther 124:290-295.

Hershko A. (1983): Ubiquitin: Roles in protein modification and breakdown. Cell 34:11-12.

Hershko A, Ciechanover A (1982): Mechanisms of intracellular protein breakdown. Ann Rev Biochem 51:335-364.

Hootman SR, Ernst SA (1988): Estimation of Na, K-Pump numbers and turnover in intact cells with $\left[{ }^{3} \mathrm{H}\right]$ ouabain. In Fleischer $S$, Fleischer B (eds): "Biomembranes Part P: ATP-driven pumps and related transport: The Na, K-pump." Methods in Enzymology' 156:213-229.

Iacovitti L. Teitelman G, Joh TH, Reis DJ (1987): Chick eye extract promotes expression of a cholinergic enzyme in sympathetic ganglia in culture. Brain Res 430:59-65.

Kotas AM, Prince AK (1987): High-affinity uptake of choline a marker for cholinergic nerve terminals is not specific in developing rat brain. Brain Res 432:175-181.

Kuhar MJ. Sethy VH, Roth RH, Aghajanian GK (1973): Choline: Selective accumulation by central cholinergic neurons. J Neurocnem 20:581-593.
Landmesser L, Pilar G (1972): The onset and development of transmission in the chick ciliary ganglion. J Physiol 222:691-713.

LeDouarin NM (1986): Cell line segregation during peripheral nervous system ontogeny. Science 231:1515-1522.

LeDouarin NM (1983): "The Neural Crest." London: Cambridge University Press.

Manaker S, Wieczorek CM, Rainbow TC (1986): Identification of sodium-dependent, high affinity choline uptake sites in rat brain with $\left[{ }^{3} \mathrm{H}\right]$ hemicholinium-3. J Neurochem 46:483-488.

Marusich MF, Pourmehr K, Weston JA (1986): Subpopulations of morphologically non-neuronal neural crest and dorsal root ganglion (DRG) cells express a sensory neuron specific epitope. Prog Clin Biol Res 217B:249-253.

Marwitt R, Pilar G, Weakly JN (1971): Characterization of two ganglion cell populations in avian ciliary ganglia. Brain Res 25:317-324.

Matsuoka I, Satake R, Kurihara K (1986): Cholinergic differentiation of clonal rat pheochromocytoma cells (PC12) induced by factors contained in glioma-conditioned medium: Enhancement of high-affinity choline uptake system and reduction of norepinephrine uptake system. Brain Res 389:145-152.

Meyer EM, West CM, Chau V (1986): Antibodies directed against ubiquitin inhibit high affinity $\left[{ }^{3} \mathrm{H}\right]$ choline uptake in rat cerebral cortical synaptosomes. J Biol Chem 261:14365-14368.

Meyer EM, West CM, Stevens BR, Chau V, Nguyen M, Judkins JH (1987): Ubiquitin-directed antibodies inhibit neuronal transporters in rat brain synaptosomes. J Neurochem 49:1815-1819.

Mykita S, Ferret B, Massarelli R (1987): Effect of external high potassium and $\mathrm{pH}$ on the uptake of choline in glial and neuronal cells in culture. Neurochem Res 12:681-685.

Narayanan CH, Narayanan Y (1978): On the origin of the ciliary ganglion in birds studied by the method of interspecific transplantation of embryonic brain regions between quail and chick. J Embryol Exp Morphol 47:137-148.

Nishi R, Berg DK (1977): Dissociated ciliary ganglion neurons in vitro: survival and synapse formation. Proc Natl Acad Sci (USA) 74:5171-5175.

Nishi R, Berg DK (1981a): Effects of high $\mathrm{K}^{+}$concentrations on the growth and development of ciliary ganglion neurons in cell culture. Dev Biol 87:301-307.

Nishi R, Berg DK (1981b): Two components trom eye tissue that differentially stimulate the growth and development of ciliary ganglion neurons in cell culture. J Neurosci 1:505-513.

Noden DM (1978): The control of avian cephalic neural crest cytodifferentiation. II. Neural tissues. Dev Biol 67:313-329.

Palouzier B, Barrit-Chamoin MC, Portalier P, Ternaux JP (1987). Cholinergic neurons in the rat nodose ganglia. Neurosci Lett 80:147-152.

Rainbow TC, Parsons B, Wieczorek CM (1984): Quantitative autoradiography of $\left[{ }^{3} \mathrm{H}\right]$ hemicholinium -3 binding sites in rat brain. Eur J Pharmacol 102:195-196.

Rauca C, Kammerer E, Matthies H (1985): The influence of enhanced $\mathrm{K}^{+}$-concentration on the uptake and acetylation of choline in hippocampus slices of rats. Biomed Biochim Acta 44:16211631.

Sandberg K, Coyle JT (1985): Characterization of $\left[{ }^{3} \mathrm{H}\right]$ hemicholinium-3 binding associated with neuronal choline uptake sites in rat brain membranes. Brain Res 348:321-330.

Schindler M, Allen ML, Olinger MR, Holland JF (1985): Automated analysis and survival selection of anchorage-dependent cells under normal growth conditions. Cytometry 6:368-374.

Sieber-Blum M, Kahn CR (1982): Suppression of catecholamine and melanin synthesis and promotion of cholinergic differentiation of quail neural crest cells by heart conditioned medium. Stem 
Cells 2:344-353.

Siegelman M, Bond MW, Gallatin MW, St. John T, Smith HT, Fried VA, Weissman IL (1986): Cell surface molecule associated with lymphocyte homing is a ubiquinated branched-chain glycoprotein. Science 231:823-829.

Smith J, Fauquet M, Ziller C, LeDouarin NM (1979): Acetylcholine synthesis by mesencephalic neural crest cells in the process of migration in vivo. Nature (London) 282:853-855.

Suszkiw JB, Pilar G (1976): Selective localization of high affinity choline uptake system and its role in ACh formation in cholinergic nerve terminals. J Neurochem 26:1133-1138.

Teitelman G, Joh TH, Grayson L, Reis DJ, Iacovitti L (1985): Cholinergic neurons of the chick ciliary ganglion express adrenergic traits in vivo and in vitro. J Neurosci 5:29-39.

Weston JA (1983): Regulation of neural crest cell migration and differentiation. In Yamada KM (ed): "Cell Interactions and Development: Molecular Mechanisms." New York: John Wiley and Sons, pp 153-184.

Weston JA, Vogel KS, Marusich MF (1988): Identification and fate of neural crest cell subpopulations in early embryonic development. In Easter SS, Barald KF, Carlson BM (eds): "Message To Mind: Directions in Developmental Neurobiology." Sunderland, Mass: Sinauer, pp 224-237.
Woodward WR, Lindstrom SH (1977): A potential screening technique for neurotransmitters in the CNS: Model studies in the cat spinal cord. Brain Res 137:37-52.

Yarden Y, Escobedo JA, Kuang W-J, Yang-Feng TL, Daniel TO, Tremble PM, Chen EY, Ando ME, Harkins RN, Francke U, Fried VA, Ullrich A, Williams LT (1986): Structure of the receptor for platelet derived growth factor helps detine a family of closely related growth factor receptors. Nature 323:226232.

Yamamura HI, Snyder SH (1972): Choline: high affinity uptake by rat brain synaptosomes. Science 178:626-628.

Yamamura HI, Snyder SH (1973): High affinity transport of choline into synaptosomes of rat brain. J Neurochem 21:1355-1374.

Ziller C, Dupin E, Brazeau P, Paulin D, LeDouarin NM (1983): Early segregation of a neuronal precursor cell line in the neural crest as revealed by culture in a chemically defined medium. Cell 32:627-638.

Ziller C, Fauquet M, Kalcheim C, Smith J, LeDouarin NM (1987): Cell lineages in peripheral nervous system ontogeny: Mediuminduced modulation of neuronal phenotypic expression in neural crest cell culture. Dev Biol 120:101-111.

Ziller C (1986): Development of neuronal properties in neural crest cells cultured in vitro. Curr Top Dev Biol 20:177-193. 